\title{
A Review of English Learning Strategy in China
}

\author{
Yanxia shen \\ School of Foreign Languages, HeBei University of Science and Technology \\ 186 East YuHua Road, ShiJiaZhuang 050018, China \\ Tel: 86-136-4321-0800 E-mail: shenyanxia21@hotmail.com \\ JuLei Song \\ School of Foreign Languages, HeBei Normal University \\ Tel: 86-138-3234-6236 E-mail: 498057319@qq.com
}

\begin{abstract}
With the attention paid to the English learning strategy training in China, more and more researchers and experts conduct empirical experiments in English classroom to test the reliability or apply the language learning strategies into learning and teaching practice. In this study, it shows distributing research on English learning strategy training with detailed data and resources. This paper analyzes the collected data and gets some findings. Some possible reasons are put forward in this research field; meantime, some implications in the research of English language learning are given in the conclusion.
\end{abstract}

Keywords: English learning strategies, Strategy training, Strategy research

\section{The development and present situation of the English learning strategy training in China}

Since six decade of $20^{\text {th }}$ century, with the development of cognitive psycholinguistics, applied linguistics and cognitive linguistics, the research on the second language acquisition developed rapidly: emphasizing on the general rules of the language learning process and the effects of language learning process and learning achievements to the learners' individual characteristics on the language learning strategy research. So the language learning strategy training gradually becomes the one of popular ways of cultivating the learning ability both in China and abroad.

All of the papers or articles collected in this study come from the CNKI database which contains not only the researches from the English professors and experts but also the Doctor and Master' thesis by the postgraduate students who are major in linguistics or linguistics and applied linguistics. From the 1980s until now, there are 38 articles published on the important and core journals in China and abroad for our Chinese scholars. (Wen, Q.F., 2003). She conducted this research from two aspects: macroscopic and microcosmic points of view. Chen Hua and Zhang Yifang (2001) studies the juveniles, Xu Yulong (2003) has done the research on primary and middle school students and Su Yuanglian (2003) concerns the high school students. And the others' researches are about the adult English learners.

Wang Duqin (1999,2002), Zheng Min (2000), Ji Kangli (2005) and Zhang Yanjun (2004) had ever done the experiments on the metacognitive strategy training. Yang Xiaohu, Zhang Wenpeng (2002), Ji Kangli (2002) and Pan Liping (2006) thereafter are engaged in the research on the metacognitive strategy from the perspective of reading comprehension, Jiang Zukang (1994), Lv Changhong (2001), Yang Jianding (2003). While Su Yuanlian (2003),Zhou Tianhao (2004) pay more attention on the metacognitive strategy training on listening class. Wen Qiufang (1996), Wu Heping (2000), Yang Wenyu (2002), He Mingchu (2004), Yu Guang, Yu Hua (2002), Li Lan (2005) proves the feasiablity and necessity of the metacognitive strategy training from different aspects. Wu Hongyun, Liu Runqing (2004) and Ji Kangli (2005) emphasize particularly on the use of metacognitive theory on the second language writing. On the other hand, Zhou Juanfen (2000), Wang Chuming (2001), Shi Yongzhenz (2002), Zhang Qingzong (2002), Xiang Maoying (2003) studies the affective strategy training of the language learners. These papers shows the importance from different aspects of English learning strategies.

\section{The research on English language strategy training abroad}

Research on language learning strategy instruction has aimed at verifying the effectiveness of strategy training. Therefore, many researchers have experimented with instructing language learners to use selected learning strategies as 
a way to improve their language performance. Weinstein (1978) invested some ninth-grade students who were trained to use a variety of elaboration strategies and apply them to reading comprehension and memory tasks. The positive results showed that these students significantly outperformed the students who received no training (O'Malley \& Chamot, 1995). Cohen and Aphek (1980) trained learners of Hebrew to recall new words by using "paired associations" and found that better performance in recall tasks occurred when learners formed associations than when associations were not formed (Ellis, 2002). In a training project to develop self-evaluation and monitoring strategies, Wenden (1987) reports that providing students with a checklist of criteria to self-evaluate their oral production resulted in successful use of self-evaluation as a learning strategy. The consensus of these investigations and others (Bialystok, 1983; Gagne, 1985; Sano, 1999; Johnson, 1999; and Dadour, 1996) tell us that language learning strategies are "teachable" and training language learners to use selected learning strategies can have positive effects on task performance and the language learning process.

In general, research on language learning strategy instruction has strongly supported the fact that it is valuable to instruct foreign language learners to have a good command of language learning strategies because proper strategy use plays a positive role in their language learning process and will ensure an ultimate attainment of the target language among the learners.

\section{The investigation and the analysis on the English learning strategy training in recent thirteen years in China.}

In the past 13 years, the articles and thesis based on the experimental study collected by the CNKI database are 171(See Table land 2). According to the research perspectives, 54 articles belong to the macroscopical topics while 117 articles go to the microscopical topics. They are all experimental researches only. (Observations, interviews, questionnaires are excluded here.) Both of the two perspectives are concerned about the objects which contained six different categories: kindergarten/primary/middle school students, college non-English majors, college English majors, college non-English postgraduates, college English postgraduates and adults. But the scopes they study are different. For the former one, it refers to five research scopes. They contain 32 matacognitive strategies, 4 cognitive strategies, 5 affective strategies, 0 social strategies and 13 learning strategies (mixed). In the latter one, five different sub-skill strategies are mentioned here: 45 listening strategies, 7 oral strategies, 25 reading strategies, 16 writing strategies and 24 lexical strategies. With regard to the research scope one and two, there are still studies which are about the relationship between sub-parts of learning strategy and sub-skill strategies (See Table 3).

For the table 1, there are 21 articles that are about non-English majors which are treated as the research objects from the point of view of metacognitive perspective. There are no researches that are related to the studies of postgraduate students' learning strategies. This phenomenon happened not only on the metacognitive part, but also on the other research scopes. Little researches have been done from the angle of middle school students or below (3). But there are more articles or thesis concerning about the metacognitive strategy (8). In another word, the study on the English majors account for one quarter of all the researches done on the metacognitive view. From the point of cognitive strategy, all the number of research papers is 4 only with 3 on non-English majors and 1 English major separately. 5 articles or thesis are gathered here about the studies on the affective strategy with 2 on middle school students and 3 on non-English majors. Strangely, there are no researches included in the social strategy part which I think will undoubtedly arouse the scholars' interests and further discussion. The reason why I put the learning strategy (mixed) here is that they are special and overall studies about those six research objects which includes at least two or three sub-strategy analyzed in table 1 . They are about not one detailed aspect but several strategies got together to intend to have a all-round understanding. The distributing pattern is more or less the same as that of metacognitive strategy but with all numbers much lower than those. They are 13 articles or thesis in all with one about middle school students, non-English majors 9 and English majors 3.

When all comes to all, there are 36 researches on the non-English majors which take up the largest proportion of all the research numbers (54). The numbers of research topics on English majors are 12 which account for one third of the former research. While the studies on the middle school students are only 6 which is half of the English majors.

Let's look at table2. Compared with the former table, this one demonstrates from the microscopical point of view about learning strategy training. It can be concluded that almost all the sub-skill strategy trainings have ever been conducted on all kinds of research objects except the English postgraduate majors. There are 45 researches about the listening strategy. 28 researches are on the non- English majors. In contrast, 13 articles or thesis are about English majors which take up half percent of the numbers of the non- English majors. Though the number is little, there are a few studies which are concerned about the adults (2), the middle school students (1) and the non- English postgraduate students (1). The second largest number regarding the sub- skill strategy is the number of reading strategy (25). There are 21 articles or theses which are related to the non- English majors. Only 3 are about the English majors and the topic about the adults is 1 . And there are no researches on other aspects. Then let's come to the writing strategy. With 11 studies on the non- English majors which account for the huge proportion, 2 are on the middle school students, 1 with English major, non- English postgraduate students and adults respectively. And the overall number studies on this part are 25 . The 
amounts of studies on the lexical strategy go near to those of reading strategy. There are 17 researches which are about the non- English majors. 5 are about English majors and 2 are on the middle school students while there is a lack of studies about both postgraduates and adults. With regard to the writing strategy, the amounts of studies about the nonEnglish majors are still the greatest number (11) whereas the total numbers are 16. 2 works over the middle school students and 1 for English majors, non- English postgraduates and adults separately. The studies about the oral strategy are only 7 which makes up the least proportion of all the researches. 5 are on the non- English majors, 1 is about the middle school students and 1 is anent the English major.

In table 3, it shows that how the metacognitive, cognitive ,affective strategies and social strategy are applied in the separate learning processes: listening, reading, speaking, writing and remembering new words. From the table it can be seen one research field which has never been investigated or discussed in the CNKI databases, that is the application on social strategy training. The conclusion ban be easily drawn that there are much more researches done on the application of metacognitive strategies than any other learning strategies. There are 32 studies on it while the total numbers of the strategy training are 41. Both the application of cognitive and affective strategy on the sub- skill learning processes are few. Five are about the affective strategy training with one related to speaking, and the other ones are about other learning processes or mixed learning processes. There are 4 researches which are concerned about the cognitive strategy training on the sub- skill learning processes in which 1 is speaking process, 1 is reading process and 1 is lexical learning process. From another point of view, 12 experiments are conducted on the listening process and it's only about the study between metacognitive strategy training and listening. From the angle of the lexical learning process, there are 6 articles or thesis about it. While both five studies deal with the reading and writing process.

\section{Results and findings from the three tables}

\subsection{Finding One}

More attention should be paid on the postgraduates and adults' English learning strategy, because the numbers of these groups are becoming increased and in order to make our teaching theory more feasible and effective, more experimental subjects should be used on testing and evaluating. Though the attention paid much more on the college or middle school students, the investigation and survey should not be neglected on the more advanced or older generations. This is the vacancy which should be explored in the future.

Another reason why the studies are conducted little on them is that the postgraduates and adults are very different from the groups mentioned before them, such as learning environment, learning experience, state of mind, learning emphasis and so on. Though the postgraduates are still the students in the campus like the others, they will have to put more energy or attention on the thesis writing (not only the M.A. thesis but also the other kinds of papers required to be published on the key journals during the studying period) and the exercise of cultivating working ability for the future (take doing some part-time jobs in spare time as an example). Most of the adults haven't learned English for many years, some even admitted they had never studied English well since they began to learn English. For the motivation of English learning, most of them are mostly to use English as a tool to communicate and they don't put this issue in the right position. In a word they are the special groups which can not be controlled easily and conveniently, and another reason are that the population of them are relatively far fewer than the others which may misguide the researchers the insignificance of the studies on them.

\subsection{Finding two}

Social learning strategy means seeking communication with target language users and language community, developing communication strategies, and getting involved as participants in authentic language use (Stern, 1975, 1983). Affective strategies is lower your anxiety such as using progressive relaxation, deep breathing, or meditation (Oxford, 1990). Social mediation makes clear the cooperation of working together with one or more peers to solve a problem, pool information, check a learning task, model a language activity, or get feedback on oral or written performance (O'Malley and Chamot, 1990). There are no experimental researches done on the social strategy training which is vacant to the scholars or researchers. More studies are needed to fill up the deficiency displayed on the tables above.

So is the affective strategy training. Affective strategy means good language learners can cope effectively with the emotional and motivational problems of language learning. Classroom learning as well as immersion in the target language environment each entails specific affective problems. In spite of these difficulties, they approach the learning task in a positive state of mind and develop the necessary energy to overcome frustrations and persist in their efforts. They cultivate positive attitudes towards the self as language learners, towards language and language learning in general, and towards the target language and its society and culture. More effective experimental researches should be done on the aspect of English learning strategy training.

\subsection{Finding three}

Many students can understand while other people are talking but can not express themselves effectively in English. For the majority for students, speaking still remains the most difficult skill which reflects the weak ability to communicate 
with others even after many years of English learning.

It is well known that the oral English teaching has been the weak aspect of our EFL teaching and its researches have not made remarkable progress as expected. The production of spoken English is considered to be one of the most difficult aspects of English learning for teachers. From the data collection, many linguists and educators have studied the objective factors of oral English teaching, e.g. English language itself and social property, but seldom take the subjects of oral English learning, namely learners into account. They mainly study the learners' content needs instead of process needs. So the methodology and procedures suggested by researchers haven't produced obvious effect on oral English teaching.

\section{Conclusion}

From this investigation mentioned above, there are so many problems existed in the English learning strategy training field, which shows the revelatory meaning for the development of English learning strategy teaching and research. First of all, the distribution of trainings and researches are unbalanced. The people who are engaged in the learning strategy researches are numerous whereas the studies of putting the researches' achievement into experimental training practices are not enough. Second, the researches of experimental subjects are still unbalanced. The studies which treat the postgraduate students and adults as the subjects are very little. Next, there are the unbalanced phenomena existing in the sub-skill strategy training. Few researches were carried through on the application of cognitive, affective especially social strategies except the metacognitive strategies. The applications of learning strategies on the oral English are still very few. So such fields still require searching and discussing in later researches.

\section{References}

Chamot, A. U. \& O. Malley, J. M. (1994). Language learner and learning strategies. In N. C. Ellis (Ed) Implicit and explicit learning of languages [M]. London: Academic.

Chen, H. \& Zhang, Y. F. (2001). A Study on Chinese Children's English Vocabulary Strategies. Foreign Language Research. No 4.

Ellis, R. (1994). The study of second language acquisition [M]. Oxford: Oxford University Press.

Nunan, D. (1997). Strategy instruction in the language classroom: an empirical investigation [J]. RELC Journal.

O’Malley, J. M. \& Chamot, A. U. (1990). Learning Strategies in second language acquisition [M]. Cambridge: Cambridge University Press.

Oxford, R. (1990). Language Learning Strategies: what every teacher should know [M]. New York: Newbury House.

OuYang, J. P. \& Hu, X. Y. (2007). College English Teaching Model based on Learning Strategies Journal of Xiangtan Normal University (Social Science Edition). No, 3

Shu, D. F. \& Zhuang, Z. X. (1996). Modern Foreign Language Teaching: Theory, Practice and Method. [M] ShangHai: ShangHai Foreign Education Press.

$\mathrm{Xu}$, Y. L. (2003). Learning Strategies and the Development of the English Reading Abilities. Foreign Language Teaching and Research, No.3

Wen, Q. F. \& Wang, L. F. (2003). Learning Strategies Training and Research in China [J]. Foreign language World, No 6

Wen, Q. F. (1996) On English Learning Strategies. [M]. ShangHai: ShangHai Foreign Education Press.

Wen, Q. F. (1996). The Trends and its Characteristics of the Changes on English Leaning Strategies by College Students. [J]. Foreign Teaching and Research, No.4

Wang, L. Q. (2002). English Language Teaching Strategies [M] BeiJin: Foreign language Teaching Press 
Table 1

\begin{tabular}{|c|c|c|c|c|c|c|c|}
\hline $\begin{array}{l}\text { Research } \\
\text { Subject } \\
\text { Research Scope }\end{array}$ & $\begin{array}{l}\text { Middle } \\
\text { School } \\
\text { Students } \\
\text { and below }\end{array}$ & $\begin{array}{l}\text { Non- } \\
\text { English } \\
\text { majors }\end{array}$ & $\begin{array}{l}\text { English } \\
\text { majors }\end{array}$ & $\begin{array}{l}\text { Non-English } \\
\text { postgraduates }\end{array}$ & $\begin{array}{l}\text { English } \\
\text { postgraduates }\end{array}$ & Adults & Total \\
\hline $\begin{array}{l}\text { Metacognitive } \\
\text { Strategy }\end{array}$ & 3 & 21 & 8 & 0 & 0 & 0 & 32 \\
\hline $\begin{array}{l}\text { Cognitive } \\
\text { Strategy }\end{array}$ & 0 & 3 & 1 & 0 & 0 & 0 & 4 \\
\hline $\begin{array}{l}\text { Affective } \\
\text { Strategy }\end{array}$ & 2 & 3 & 0 & 0 & 0 & 0 & 5 \\
\hline $\begin{array}{l}\text { Social } \\
\text { Strategy }\end{array}$ & 0 & 0 & 0 & 0 & 0 & 0 & 0 \\
\hline $\begin{array}{l}\text { Learning trategy } \\
\text { (mixed) }\end{array}$ & 1 & 9 & 3 & 0 & 0 & 0 & 13 \\
\hline Total & 6 & 36 & 12 & 0 & 0 & 0 & 54 \\
\hline
\end{tabular}

Table 2

\begin{tabular}{|c|c|c|c|c|c|c|c|}
\hline $\begin{array}{l}\text { Research } \\
\text { Subject } \\
\text { Research Scope }\end{array}$ & $\begin{array}{l}\text { Middle } \\
\text { School } \\
\text { Students } \\
\text { and below }\end{array}$ & $\begin{array}{l}\text { Non- } \\
\text { English } \\
\text { majors }\end{array}$ & $\begin{array}{l}\text { English } \\
\text { majors }\end{array}$ & $\begin{array}{l}\text { Non-English } \\
\text { postgraduates }\end{array}$ & $\begin{array}{l}\text { English } \\
\text { postgraduates }\end{array}$ & Adults & Total \\
\hline $\begin{array}{l}\text { Listening } \\
\text { Strategy }\end{array}$ & 1 & 28 & 13 & 1 & 0 & 2 & 45 \\
\hline $\begin{array}{l}\text { Speaking } \\
\text { Strategy }\end{array}$ & 1 & 5 & 1 & 0 & 0 & 0 & 7 \\
\hline $\begin{array}{l}\text { Reading } \\
\text { Strategy }\end{array}$ & 0 & 21 & 3 & 0 & 0 & 1 & 25 \\
\hline $\begin{array}{l}\text { Writing } \\
\text { Strategy }\end{array}$ & 2 & 11 & 1 & 1 & 0 & 1 & 16 \\
\hline $\begin{array}{l}\text { Lexical } \\
\text { Strategy }\end{array}$ & 2 & 17 & 5 & 0 & 0 & 0 & 24 \\
\hline Total & 6 & 82 & 23 & 2 & 0 & 4 & 117 \\
\hline
\end{tabular}

Table 3

\begin{tabular}{|l|l|l|l|l|l|l|l|}
\hline & Listening & Speaking & Reading & Writing & Lexicon & Others & Total \\
\hline $\begin{array}{l}\text { Metacognitive } \\
\text { Strategy }\end{array}$ & 12 & 0 & 4 & 5 & 5 & 6 & 32 \\
\hline $\begin{array}{l}\text { Cognitive } \\
\text { Strategy }\end{array}$ & 0 & 1 & 1 & 0 & 1 & 1 & 4 \\
\hline $\begin{array}{l}\text { Affective } \\
\text { Strategy }\end{array}$ & 0 & 1 & 0 & 0 & 0 & 4 & 5 \\
\hline $\begin{array}{l}\text { Social } \\
\text { Strategy }\end{array}$ & 0 & 0 & 0 & 0 & 0 & 0 & 0 \\
\hline Total & 12 & 2 & 5 & 5 & 6 & 11 & 41 \\
\hline
\end{tabular}

